\title{
USE OF INDIGENOUS TECHNOLOGY FOR THE PRODUCTION OF HIGH QUALITY CASSAVA FLOUR WITH SIMILAR FOOD QUALITIES AS WHEAT FLOUR
}

\author{
Ogbonnaya Chinedum Eleazu ${ }^{1 \bowtie}$, Kate Chinedum Eleazu², Segun Kolawole ${ }^{3}$
}

${ }^{1}$ National Root Crops Research Institute - NRCRI, Umudike, Nigeria

${ }^{2}$ Michael Okpara University of Agriculture, Umudike

PMB 7267, Umuahia, Abia State, Nigeria

${ }^{3}$ Department of Microbiology/Pathology, National Root Crops Research Institute, Umudike, Nigeria

\begin{abstract}
Background. The aim of the paper was to compare the food qualities of 2 varieties (SME 1 and 2) of high quality cassava flour (HQCF) produced from indigenous technology and that of some commercially sold wheat/HQCF samples.

Material and methods. The $\mathrm{pH}$, proximate, phytochemical, antioxidant, functional properties and starch yield of the flours were carried out using standard techniques.

Results. The wheat flours had higher bulk densities and lipids than the HQCF samples while the oil absorption capacity of the HQCF (SME 2) was higher than other flour samples investigated. The antioxidant assays of the flours showed that they contained considerable levels of antioxidants with the HQCF sample from DAT having higher antioxidants than other flour samples studied. The HQCF (SME 1) had significantly higher $(P<0.05)$ starch content among the flour samples. The bacteria counts of the HQCF samples ranged from 0 to $1.4 \times 10^{4} \mathrm{cfu} / \mathrm{ml}$ while the fungal count ranged from 0 to $2 \times 10^{-3}$ with the unbranded wheat flour having the highest microbial load compared with other flour samples studied.

Conclusion. The use of this indigenous technology produces HQCF with lower lipids, microbial contamination but higher flavour retaining ability, flavonoids and starch contents than wheat flour. The significant positive correlation $\left(R^{2}=0.872\right)$ between reducing power of the samples and their DPPH antioxidant activity indicate that either could be used to assay for the total antioxidant activity of cassava and wheat flour. The study underscores the need to buy flour from branded companies to reduce the risks of microbial contamination.
\end{abstract}

Key words: high quality cassava flour, indigenous technology, wheat flour

\section{INTRODUCTION}

Nigeria is one of the largest importers of American red winter wheat [FAO 2004] with annual importation of over one million tons, making them completely dependent on imported wheat for their confectioneries. Cassava (Manihot esculenta Crantz) is one of the most important crops in Africa. As a food crop, it fits well into the farming system of small holder farmers in Nigeria because it is available all year round, thus providing household food security [Ukwuru and Egbonu 2013]. The tubers can be kept up to two years in the ground, prior to harvesting but once harvested, they begin to deteriorate. This is because the fresh

『eleazon@yahoo.com, phone: +2348034164686 
roots contain high moisture [Eleazu et al. 2011], making their transportation from rural areas difficult and expensive.

To forestall early deterioration and because of its bulky nature, cassava is usually traded in its processed form [Ukwuru and Egbonu 2013]. Processing the tuber into a dry form reduces its moisture content by converting it into a more durable product.

High quality cassava flour (HQCF) is a promising market that has gained popularity in West Africa over the past few years [Komlaga et al. 2012]. The use of HQCF can serve as a replacement for wheat flour in the bakery sector and as an alternative or component in traditional cassava products such as: instant $f u f u$ (doe) in Ghana or fermented fufu in Nigeria.

One of the measures that was put in place for the adoption of HQCF technology in Nigeria was the Presidential Initiative on Cassava, launched in Nigeria in 2003 with the aim of inclusion of $10 \%$ cassava flour to the wheat flour used in bread making [Sanni et al. 2009].

Despite the efforts by the Nigerian government for the sustenance of the HQCF technology and irrespective of the fact that the use of HQCF for the production of baked goods, if feasible, could help to lower the dependence of Nigerians on imported wheat, many Nigerians are still hesitant on incorporating it into wheat flour, for their confectionaries at different levels of substitution. One of the reasons that has been given by those in the bakery sector for the slow adoption of this technology is the fear of the presence of toxic principles in cassava, its bulkiness, short shelf life of the baked product, arising from increased moisture and microbial growth (personal communication).

Since the use of HQCF for the production of baked goods, if feasible, could lower the dependence of Nigeria on imported wheat and being that the method of flour preparation is important in determining the quality of the cassava flour for confectionaries, this study was set out to comparatively analyse, the food qualities (physicochemical properties, phytochemical composition, antioxidant activities and microbial load) of HQCF produced from indigenous technology and that of some commercially sold wheat and HQCF samples.

\section{MATERIAL AND METHODS}

Three samples of high quality cassava flour (HQCF) and two samples of wheat flour (WF) were used for the study. The HQCF samples labeled (SME 1) and (SME 2) were the flour samples of two different varieties of cassava from a private farmer intending to go into bread production, the HQCF labeled DAT (HQCF control) was obtained from a commercial HQCF company, the $100 \%$ wheat flour (unbranded) was obtained from the open market while the sample labeled HW was obtained from a branded company involved in commercial production of wheat flour.

\section{Preparation of HQCF using indigenous technology}

The method employed for the preparation of the HQCF samples (SME 1 and SME 2) involved: peeling, washing, cutting into chips, grating to mash, dewatering in clean bags, disintegration of lumps (of particle size about $3 \mathrm{~mm}$ ), sun drying on a raised platform, milling into flour and sieving of the particles with muslin cloth to obtain high quality cassava flour (HQCF).

\section{Starch extraction}

One hundred grams of each flour sample was dissolved in distilled water and left overnight. Each mixture was filtered through a triple-layered cheese cloth and the starch washed thoroughly with distilled water in pre-weighed beakers. The granules were allowed to sediment for 4 to $5 \mathrm{~h}$ after which the water was decanted and the wet cakes sun dried and re-weighed for starch yield.

\section{Determination of starch yield}

The starch yield of the flours was calculated as:

$$
\frac{W_{2}-W_{1}}{W_{0}} \cdot 100
$$

where: $W_{0}$ - weight of sample, $W_{1}$ - weight of empty beaker, $W_{2}$ - weight of beaker + sample after drying.

\section{Analysis of the functional properties of the flours}

The bulk density, $\mathrm{pH}$, water absorption capacity (WAC), oil absorption capacity (OAC), gelatinization 
temperature and emulsification capacities of the flour samples were determined using the method of Onwuka [2005].

\section{$\mathrm{pH}$}

The $\mathrm{pH}$ of the flour samples was measured by making a $10 \%(\mathrm{w} / \mathrm{v})$ suspension of each sample in distilled water. The suspensions were mixed thoroughly and the pH measured with a Hanna pH meter (Model HI1270).

\section{Proximate analysis}

The percentage moisture, ash, lipid and protein contents of the flour samples were determined using the method of AOAC [1990]. The percentage carbohydrate contents of the samples were obtained by difference, their energy values were calculated using the Atwater Formula and results were expressed as $\mathrm{Kcal} / 100 \mathrm{~g}$.

\section{Phytochemical analysis}

The gravimetric method of Harborne [1973] was used for the determination of total alkaloids, the method of Okwu [2004] was used in the determination of the total flavonoids, the alkaline picrate method of Onwuka [2005] was used for the determination of the cyanide while the AOAC method [1990] was used for the determination of the tannin content of the flours.

\section{Antioxidant assays}

The DPPH free radical scavenging assays of the flour were determined using the method of Blois [1985] while the reducing power of the samples was determined using the method of Pulido et al. [2000]. Quercetin was used as the standard for both assays.

\section{Microbial assay}

The total viable counts of the flour samples were determined using the Pour Plate Technique [Fawole and Oso 1986]. The bacterial and fungal identification were done using the methods of Buchannan and Gibbons [1975] and Barnet and Hunter [1987].

\section{Statistical analysis}

Data was subjected to analysis using the statistical package for social sciences (SPSS), version 15.0. Results are presented as means \pm standard deviations. One way analysis of variance (ANOVA) was used for the comparison of the means. Differences between means were considered to be significant at $P<0.05$ using the Duncan Multiple Range Test.

\section{RESULTS AND DISCUSSION}

The higher bulk density of the wheat flour samples investigated as shown in Table 1, compared with the cassava flour samples, is a significant finding in this study as this suggests that wheat flours are heavier than cassava flours in terms of particle size.

Water absorption capacity measures the ability of a flour to absorb water and swell for improved consistency in food [Okezie and Bello 1988] while oil absorption capacity (OAC) is important because it acts as flavour retainer and increases the mouth feel of foods. The major chemical compositions that enhance the water absorption capacities of flours are proteins and carbohydrates since these constituents contain hydrophilic parts such as polar or charged side chains. The changes in the WAC and OAC of the flour samples might be attributed to the number and nature of the water-binding sites, structure, and chemical composition. The higher WAC of the HQCF from DAT Company as shown in Table 1, compared with other flour samples investigated, could be indicative of higher polar amino acid residues of proteins having an affinity for water molecules and this is an advantage for it in this regard while the higher OAC of HQCF (SME 2) obtained from indigenous technology, compared with other flour samples as shown in Table 1 , indicates possibilities of better flavour retainer than other flour samples.

Gelatinization temperature is the temperature at which starch molecules in a food substance lose their structure and leach out from the granules as swollen amylase and it affects the time required for the cooking of food substances. Results obtained in this study, as shown in Table 1, indicate that the gelatinization temperature of all the flour samples investigated fell within the range given by ARSO [2012]. In addition, the wheat flour samples were observed to have higher gelatinization temperature than the HQCF samples and this is a significant finding in this study.

The $\mathrm{pH}$ of a flour suspension is important since some functional properties such as solubility, emulsifying activity and foaming properties are affected 
Eleazu O.C., Eleazu K.C., Kolawole S., 2014. Use of indigenous technology for the production of high quality cassava flour with similar food qualities as wheat flour. Acta Sci. Pol., Technol. Aliment. 13(3), 249-256.

Table 1. Physical properties of different samples of HQCF and wheat flour

\begin{tabular}{lcccccc}
\hline \multicolumn{1}{c}{ Samples } & $\begin{array}{c}\text { Bulk density } \\
\mathrm{g} / \mathrm{ml}\end{array}$ & $\begin{array}{c}\text { Water absorp- } \\
\text { tion capacity } \\
\mathrm{g} / 100 \mathrm{~g}\end{array}$ & $\begin{array}{c}\text { OAC } \\
\%\end{array}$ & $\begin{array}{c}\text { Gelatinization } \\
\text { temperature } \\
{ }^{\circ} \mathrm{C}\end{array}$ & $\mathrm{pH}$ & $\begin{array}{c}\text { E.C. } \\
\%\end{array}$ \\
\hline HQCF (1) & $0.66 \pm 0.04$ & $170 \pm 0.24$ & $190 \pm 0.04$ & $60 \pm 0.10$ & 5.08 & $52.94 \pm 0.11$ \\
HQCF (2) & $0.59 \pm 0.07$ & $170 \pm 0.20$ & $220 \pm 0.12$ & $60 \pm 0.14$ & 5.23 & $55.88 \pm 0.10$ \\
HQCF (DAT) & $0.68 \pm 0.05$ & $175 \pm 0.31$ & $190 \pm 0.11$ & $58 \pm 0.18$ & 4.75 & $52.94 \pm 0.08$ \\
$\begin{array}{l}\text { 100\% wheat flour } \\
\text { (unbranded) }\end{array}$ & $0.77 \pm 0.03$ & $170 \pm 0.29$ & $180 \pm 0.17$ & $70 \pm 0.23$ & 6.82 & $52.94 \pm 0.10$ \\
HW wheat flour & $0.82 \pm 0.02$ & $160 \pm 0.15$ & $180 \pm 0.20$ & $61 \pm 0.19$ & 6.38 & $51.43 \pm 0.17$ \\
ARSO Standard & & & & & & \\
\hline
\end{tabular}

Values are the means $\pm \mathrm{SD}$ of triplicate experiments.

SI - solubility index, EC - emulsion capacity, OAC - oil absorption capacity.

by it. High $\mathrm{pH}$ starches have been reported to have increased solubility because of increased hydrophilic characters of the starch at these $\mathrm{pH}$ values [Tsakama et al. 2010]. Results obtained in this study, as shown in Table 1, indicate that the $\mathrm{pH}$ of the unbranded wheat flour and that obtained from HW Company, fell within the specified requirement of ARSO [2012] while that from DAT was below the acceptable range and lower than those produced from indigenous technology.

Emulsion capacity simply determines the maximum amount of oil that can be emulsified by protein. Values shown in Table 1 indicate that all the flours had moderate emulsion capacities.
The DPPH assay is a widely accepted method for the determination of the antioxidant activities of various food systems. As observed in this study, the DPPH antioxidant activities of the flours decreased in the following order: HQCF (DAT) > HQCF $($ SME1) $>$ HQCF $($ SME 2) $>100 \%$ wheat flour (nbranded) $>$ HW wheat flour (Table 2).

The DPPH assay is limited to neutral and higher $\mathrm{pH}$ applications and also suffers from colour interference [Choong et al. 2007] and this informed the assay of the reducing power of the flours. Reducing power assay employs the reduction of $\mathrm{Fe}^{3+}$ to $\mathrm{Fe}^{2+}$ through electron transfer. This method serves as a good indicator of

Table 2. DPPH scavenging activity and reducing power of different samples of HQCF and wheat flour

\begin{tabular}{lccccccc}
\hline \multicolumn{1}{c}{ Samples } & $\begin{array}{c}\text { DPPH } \\
\text { scavenging } \\
\text { activity } \\
\%\end{array}$ & $\begin{array}{c}\text { Reducing } \\
\text { power-con- } \\
\text { centration } \\
\mathrm{mg} / \mathrm{ml}\end{array}$ & $\begin{array}{c}\text { HQCF (1) } \\
\text { (absorbance) } \\
\mathrm{nm}\end{array}$ & $\begin{array}{c}\text { HQCF (2) } \\
\text { (absorbance) } \\
\mathrm{nm}\end{array}$ & $\begin{array}{c}\text { HQCF } \\
\text { (DATCO) } \\
\text { (absorbance) } \\
\mathrm{nm}\end{array}$ & $\begin{array}{c}100 \% \text { wheat } \\
\text { flour } \\
\text { (unbranded) } \\
\text { (absorbance) } \\
\mathrm{nm}\end{array}$ & $\begin{array}{c}\text { Honeywell } \\
\text { wheat } \\
\text { (absorbance) } \\
\mathrm{nm}\end{array}$ \\
\hline HQCF (SME 1) & $50.25 \pm 7.58$ & 177.78 & $1.318 \pm 0.114$ & $1.156 \pm 0.052$ & $1.654 \pm 0.174$ & $1.471 \pm 0.022$ & $1.25 \pm 0.09$ \\
HQCF (SME 2) & $49.49 \pm 1.01$ & 200 & $1.614 \pm 0.044$ & $1.618 \pm 0.112$ & $1.72 \pm 0.072$ & $1.685 \pm 0.110$ & $1.596 \pm 0.04$ \\
HQCF (DAT) & $51.15 \pm 0.97$ & 226.67 & $2.037 \pm 0.172$ & $1.968 \pm 0.104$ & $2.249 \pm 0.023$ & $1.842 \pm 0.044$ & $1.982 \pm 0.11$ \\
$\begin{array}{l}100 \% \text { wheat flour } \\
\text { (unbranded) }\end{array}$ & $47.71 \pm 3.99$ & 228.67 & $2.425 \pm 0.083$ & $2.404 \pm 0.051$ & $2.527 \pm 0.050$ & $2.009 \pm 0.017$ & $2.107 \pm 0.02$ \\
HW wheat flour & $44.40 \pm 5.27$ & 320 & $2.747 \pm 0.014$ & $2.801 \pm 0.082$ & $2.806 \pm 0.055$ & $2.861 \pm 0.061$ & $2.442 \pm 0.051$ \\
\hline
\end{tabular}

Values are the means $\pm \mathrm{SD}$ of duplicate experiments. 
the antioxidant capacity of any plant since antioxidants are good reducing agents. As shown in Table 2, the reductive capacities of the samples decreased in the order: HQCF $($ DAT) $>$ HQCF 1 (SME 1) $>$ HQCF 2 (SME 2) $>100 \%$ wheat flour (unbranded) $>\mathrm{HW}$ wheat flour.

The ash content of a sample is a measure of its total inorganic mineral content. Results shown in Table 3, indicate that all the wheat flour samples contained higher mineral contents than the HQCF samples. The HQCF samples contained higher moisture than the wheat flours and this was expected as cassava is known to contain very high moisture content. In addition, the values that were obtained for moisture in all the flour samples as shown in Table 3 were low and they fell within the range given by ARSO [2012].

The percentage lipid contents of the flour samples ranged from 0.23 to 1.56 . The wheat flour samples were observed to possess higher lipid contents than the cassava samples (Table 3 ).

Crude fibre is used as an index of evaluation of dietary fibre contents which serves as a useful tool in the control of oxidative processes in food products [Eleazu et al. 2011]. The crude fibre contents of all the flour samples investigated, as shown in Table 3 , conformed to the standard of ARSO [2012] with higher values seen in the unbranded wheat flour sample.

Phenolic compounds refer to a class of compounds containing a benzene ring with one or more hydroxyl groups, derived from the secondary metabolism of plants that affect the taste, odour, colour, qualities, nutritional and antioxidant properties of foods. The phenolic compounds in plants include: flavonoids, alkaloids, condensed tannins, etc.

Tannins can cause browning in both fresh foods and processed products [Chikezie et al. 2008]. Results shown in Table 4, indicate that the unbranded wheat flour sample, contained significantly $(P<0.05)$ higher quantities of tannins compared with the HQCF (SME 1) and Honeywell wheat flour samples investigated but not significantly different from that of the HQCF (SME 2).

Flavonoids are potent water soluble antioxidants that prevent oxidative cell damage with anti-carcinogenic actions. As shown in Table 3, the HQCF (SME 2$)$ contained significantly $(P<0.05)$ higher quantities of flavonoids compared with other samples investigated and this confers better potentials to it in terms of antioxidants.

Cyanogenic glucosides are compounds that yield glucose, hydrogen cyanide and aldehyde or ketone upon hydrolysis with an acid or enzyme. This cyanide could be lethal as it intercalates with cytochrome oxidase for aerobic function [Bolhius 1954].

The lethal dose of cyanide in humans has been reported to range from $50-300 \mathrm{mg} / \mathrm{kg}$ body weight [Bolhius 1954, Akiyama et al. 2006]. Surprisingly, the wheat samples obtained from the open market as

Table 3. Phytochemical composition of different samples of HQCF and wheat flour, \%

\begin{tabular}{|c|c|c|c|c|c|c|c|c|}
\hline Samples & Ash & $\begin{array}{l}\text { Moisture } \\
\text { content }\end{array}$ & Lipid & Crude fibre & Tannin & Flavonoid & $\begin{array}{l}\text { Cyanide } \\
\mathrm{mg} / \mathrm{kg}\end{array}$ & Alkaloid \\
\hline HQCF (1) & $0.39 \pm 0.01^{\mathrm{a}}$ & $8.72 \pm 0.03^{b}$ & $0.27 \pm 0.04^{\mathrm{a}}$ & $0.80 \pm 0.14^{b}$ & $0.07 \pm 0.01^{\mathrm{a}}$ & $0.70 \pm 0.00^{\text {cd }}$ & $0.07 \pm 0.01^{\mathrm{a}}$ & $0.60 \pm 0.07^{\mathrm{a}}$ \\
\hline HQCF (2) & $1.30 \pm 0.14^{\mathrm{bc}}$ & $9.99 \pm 0.41^{\mathrm{c}}$ & $0.37 \pm 0.06^{\mathrm{a}}$ & $1.30 \pm 0.57^{\mathrm{c}}$ & $1.48 \pm 0.06^{\mathrm{c}}$ & $0.90 \pm 0.14^{\mathrm{e}}$ & $0.58 \pm 0.01^{\mathrm{a}}$ & $1.15 \pm 0.02^{\mathrm{bcd}}$ \\
\hline $\begin{array}{l}\text { HQCF } \\
\text { (DAT) }\end{array}$ & $1.75 \pm 0.10^{\text {cdef }}$ & $8.41 \pm 0.03^{b}$ & $0.50 \pm 0.14^{\mathrm{a}}$ & $1.30 \pm 0.21^{\mathrm{c}}$ & $0.08 \pm 0.00^{\mathrm{a}}$ & $0.35 \pm 0.07^{\mathrm{b}}$ & $0.39 \pm 0.26^{\mathrm{a}}$ & $1.95 \pm 0.21^{\mathrm{e}}$ \\
\hline $\begin{array}{l}100 \% \\
\text { wheat flour } \\
\text { (unbranded) }\end{array}$ & $2.00 \pm 0.28^{\mathrm{def}}$ & $4.77 \pm 0.24^{\mathrm{a}}$ & $1.10 \pm 0.28^{\mathrm{bc}}$ & $1.80 \pm 0.25^{\mathrm{d}}$ & $1.60 \pm 0.28^{\mathrm{c}}$ & $0.35 \pm 0.07^{\mathrm{b}}$ & $10.91 \pm 3.45^{\mathrm{d}}$ & $1.00 \pm 0.00^{\mathrm{b}}$ \\
\hline HW flour & $2.10 \pm 0.14^{\mathrm{f}}$ & $4.21 \pm 0.30^{\mathrm{a}}$ & $1.23 \pm 0.33^{\mathrm{bcd}}$ & $1.30 \pm 0.14^{\mathrm{c}}$ & $0.09 \pm 0.01^{\mathrm{a}}$ & $0.00 \pm 0.00^{\mathrm{a}}$ & $5.81 \pm 0.11^{\mathrm{bcd}}$ & $1.40 \pm 0.14^{\mathrm{cd}}$ \\
\hline $\begin{array}{l}\text { ARSO } \\
\text { Standard }\end{array}$ & & $\begin{array}{l}\operatorname{maximum} \\
\text { of } 12 \%\end{array}$ & & & & & $\begin{array}{l}\text { maximum } \\
\text { of } 10 \mathrm{mg} / \mathrm{kg}\end{array}$ & \\
\hline
\end{tabular}

Values are the means $\pm \mathrm{SD}$ of triplicate experiments.

Means with different superscripts along each vertical column are significantly different $(P<0.05)$. 
Eleazu O.C., Eleazu K.C., Kolawole S., 2014. Use of indigenous technology for the production of high quality cassava flour with similar food qualities as wheat flour. Acta Sci. Pol., Technol. Aliment. 13(3), 249-256.

Table 4. Total viable counts of bacteria and fungi on NA, MA and PDA plates

\begin{tabular}{|c|c|c|c|c|c|}
\hline Samples & NA $\left(10^{3}\right)$ & $\operatorname{MA}\left(10^{3}\right)$ & $\operatorname{PDA}\left(10^{3}\right)$ & Bacteria isolated & Fungi isolated \\
\hline $\operatorname{HQCF}(1)$ & $2 \times 10^{3}$ & nil & nil & Lactobacillus & nil \\
\hline HQCF (2) & $6 \times 10^{3}$ & nil & $2 \times 10^{3}$ & $\begin{array}{c}\text { Staphylococcus, } \\
\text { Bacillus }\end{array}$ & Aspergillus flavus \\
\hline HQCF (DAT) & $5 \times 10^{3}$ & nil & nil & $\begin{array}{c}\text { Staphylococcus, } \\
\text { Bacillus }\end{array}$ & nil \\
\hline $\begin{array}{l}100 \% \text { wheat flour } \\
\text { (unbranded) }\end{array}$ & $1.4 \times 10^{4}$ & nil & $2 \times 10^{3}$ & $\begin{array}{c}\text { Lactobacillus, } \\
\text { Staphylococcus, } \\
\text { Bacillus }\end{array}$ & Aspergillus niger \\
\hline HW wheat flour & nil & nil & nil & nil & nil \\
\hline ARSO requirement & & & & $\begin{array}{l}\operatorname{maximum}: 2 \times 10^{2} \\
\mathrm{cfu} / \mathrm{ml} \text { for Staph }\end{array}$ & \\
\hline
\end{tabular}

shown in Table 3, contained significantly higher quantities of cyanide than the HQCF samples despite having higher $\mathrm{pH}$. For cassava flour, $10 \mathrm{mg} \mathrm{HCN} / \mathrm{kg}$ is recommended [Codex... 1985]. One plausible explanation for the higher cyanide contents of the wheat flour samples could be the effect of alkaline hydrolysis of the grains by the alkaline picrate, that releases phenol aglycons from ester and glycoside compounds within cell-wall polysaccharides [Rispail et al. 2005, Litvinenko and Makarov 1969]. It is thus possible that this method may not have given a true picture of the cyanogenic glycoside contents of the wheat flours. It will therefore be worthwhile to further characterise the phenolic profile to validate our claim.

Alkaloids are the most efficient therapeutic plant phytochemicals as they confer antimicrobial properties to various plants [Eleazu et al. 2011]. As shown in Table 3, the HQCF sample obtained from DATCO company, was observed to contain significantly $(P<$ $0.05)$ higher quantities of alkaloids compared with other flour samples investigated.

The mean bacteria counts of the HQCF samples ranged from $2 \times 10^{3}$ to $1.4 \times 10^{4} \mathrm{cfu} / \mathrm{ml}$ as shown in Table 4. The HQCF sample (1) was observed to have lower microbial load, compared with the HQCF (2), HQCF (DAT) and the unbranded flour except the Honey well wheat flour. In addition, all the flour samples analysed, had higher staphylococcus isolates compared with the standard of ARSO [2012]. However, the amount of staph isolates in the HQCF (SME 1),
HQCF (SME 2) and HW wheat flour samples fell within the standard given by FAO [2004] while that of the unbranded wheat flour didn't conform to this standard. The higher bacterial load of the unbranded wheat flour, despite its lower moisture contents compared with the HQCF samples, shows that apart from moisture, the processing environment of food samples could play contributory roles to their contamination by microorganisms.

The sterile quality of the wheat flour from honey well is the most significant finding in this present study and this could be attributed to its low moisture content in addition to its processing environment. Further microbial analysis, indicated the absence of enteric bacteria in all the flour samples analysed.

The fungi counts of the flour samples ranged from 0 to $2 \times 10^{3}$ as shown in Table 4 . The microorganisms isolated in this study include: Lactobacillus spp., Staphylococcus, Bacillus, Aspergillus flavus, Penicillum spp. and Aspergillus niger. Although these organisms are potentially pathogenic, their counts recorded (less than $10 \mathrm{cfu}$ units $/ \mathrm{ml}$; except the $100 \%$ unbranded) are quite low to cause any deleterious effect. Results obtained for microbes in these flours (except the unbranded wheat flour) are consistent with that of FAO [2004] indicating that their shelf life could be increased if packaged well and stored. This study shows the microbial hazards associated with buying unbranded flour samples. 
Eleazu O.C., Eleazu K.C., Kolawole S., 2014. Use of indigenous technology for the production of high quality cassava flour with similar food qualities as wheat flour. Acta Sci. Pol., Technol. Aliment. 13(3), 249-256.

The starch contents of the flour samples, as shown in Figure 1 on dry weight basis, ranged from 63.15 to $81.35 \%$. The HQCF sample (SME 1) contained the highest starch content $(81.35 \pm 0.04 \%)$ while the HQCF sample (2) possessed the least (63.15 $\pm 0.22 \%)$.

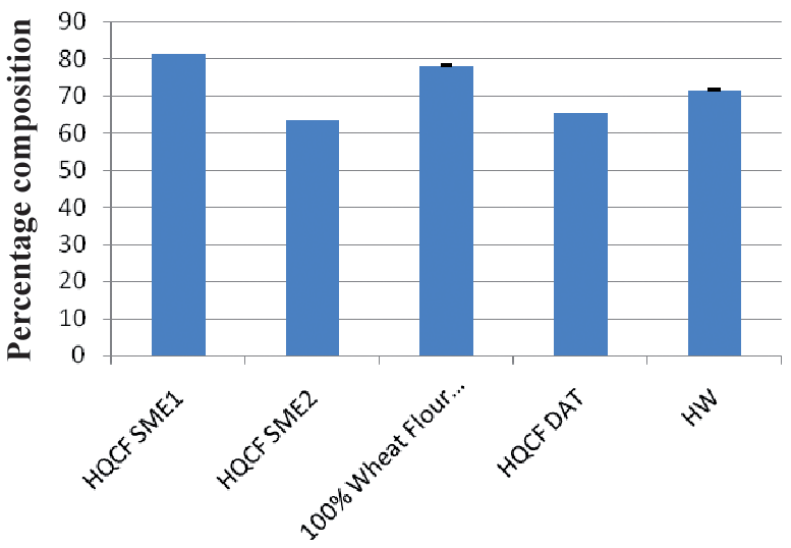

ARSO Standard: Minimum of $65 \%$ on dry weight basis.

Fig. 1. Percentage starch composition of HQCF and wheat flour samples

Correlation analysis carried out revealed that there was significant positive correlation between reducing power of the samples and their DPPH antioxidant activity $\left(R^{2}=0.872\right.$; Table 5$)$ indicating that either could be used to assay for the total antioxidant activity of $\mathrm{HQCF}$ and wheat flour.

Table 5. Correlation between reducing power and DPPH antioxidant activities

\begin{tabular}{cc}
\hline Parameter & DPPH activity \\
\hline Reducing power & $0.872 *$ \\
\hline
\end{tabular}

*Significant at $P<0.01$ level.

\section{CONCLUSIONS}

The use of this indigenous technology produces HQCF with lower lipids, microbial contamination but higher flavor retaining ability, flavonoids and starch contents than wheat flour while wheat flour was found to contain higher amounts of minerals, lipids, bulk density, crude fibre and tannins than HQCF.

The higher bacterial load of the $100 \%$ wheat flour sample obtained from the open market, despite its low moisture contents shows the microbial hazards associated with buying unbranded flour samples.

\section{REFERENCES}

Akiyama H., Toida T., Sakai S., Amakura Y., Kondo K., Sugita-Kunishi Y., Maitani T., 2006. Determination of cyanide and thiocyanate in Sugihirata Ke mushroom using HPLC method with fluorimetric detection. J. Health Sci. 52, 73-77.

AOAC, 1990. Methods of the Association of Official Analysis Chemists. Official methods of analysis. Virginia Assoc. Off. Anal. Chem. USA, 1141.

ARSO, 2012. High quality cassava flour - Specification. African Organization for Standardization Nairobi, Kenya.

Barnet H.L., Hunter B.B., 1987. Ilustrated genera of imperfect fungi. Macmillan New York.

Blois M.S., 1985. Antioxidant determination by use of stable free radicals. Nature 29, 1199-1200.

Bolhius G.G., 1954. The toxicity of cassava roots. Neth. J. Agric. 2, 176-185.

Buchanan R.E., Gibbon N.E., 1975. Bergey's manual of determinative bacteriology. Williams and Wilkins Baltimore.

Chikezie P.C., Agomuo E.N., Amadi B.A., 2008. Biochemistry. Practical/research method. A fundamental approach. Mega Soft Publ. 2, 51-53.

Choong C.T., Van-Den T., Roger F.M., Roger L., Thompson L., Kenneth V.P., Yencho G.C., 2007. Antioxidant activities, phenolic and $\beta$-carotene contents of sweet potato genotypes with varying flesh colours. Food Chem. 103, 829-838.

Codex Alimentarius Commission, 1985. Report of the Seventh Session of the Codex Coordinating Committee for Africa. FAO WHO Nairobi, Kenya.

Eleazu C.O., Amajor J.U., Ikpeama A.I., Awa E., 2011. Studies on the nutrient composition, antioxidant activities, functional properties and microbial load of the flours of 
10 elite cassava (Manihot esculenta) varieties. Asian J. Clin. Nutr. 3 (1), 33-39.

FAO, 2004. Food and Agriculture Organization. Statistics Series No. 95. Food and Agriculture Organization of the United Nations Rome.

Fawole N.V., Oso E.A., 1986. Laboratory manual of microbiology. Spectrum Books Ibadan, Nigeria, 34-35.

Harbone J.B., 1973. Comparative biochemistry of the flavonoids. Academic Press New York, 221-222.

Komlaga G.A., Glover-Amengor M., Dziedzoave N.T., Hagan L.L., 2012. Consumer acceptability of wheat/ cassava composite bread. World Rural Observ. 4(2), 1-4.

Litvinenko V.I., Makarov V.A., 1969. The alkaline hydrolysis of flavonoid glycosides. Chem. Nat. Comp. 5, 305-306

Okezie B.O., Bello A.B., 1988. Physicochemical and functional properties of winged bean flour and isolate compared with soy Isolate. J. Food Sci. 53, 450-454.

Okwu D.E., 2004. Phytochemicals and vitamin content of indigenous spices of Southeastern Nigeria. J. Sustain. Agric. Environ. 6(1): 30-37.
Onwuka G.I., 2005. Food analysis and instrumentation. Theory and practice. Napthali Lagas Nigeria, 140-146.

Pulido R., Bravo L., Saura C.F., 2000. Antioxidant activity of dietary polyphenols as determined by a modified ferric reducing/antioxidant power assay. J. Agric. Food Chem. 48, 396-3402.

Rispail N., Morris P., Webb K.J., 2005. Phenolic compounds: Extraction and analysis. In: Lotus japonicus handbook. Ed. A.J. Márquez. Springer Dordrecht, 349-354.

Sanni L.O., Onadipe O.O., Ilona P., Mussagy M.D., Abass A., Dixon A.G.O., 2009. Successes and challenges of cassava enterprises in West Africa: a case study of Nigeria, Bénin, and Sierra Leone. Int. Inst. Trop. Agric. (IITA) Ibadan, Nigeria, 1-25.

Tsakama M., Mwangwela A.M., Manani T.A., Mahungu N.M., 2010. Physicochemical and pasting properties of starch extracted from eleven sweetpotato varieties. African J. Food Sci. Techn. 1 (4), 90-98.

Ukwuru M.U., Egbonu S.E., 2013. Recent development in cassava-based products research. Acad. J. Food. Res. 1 (1), 1-13.

Accepted for print - Zaakceptowano do druku: 21.03.2014

Received - Przyjęto: 28.11.2013

For citation - Do cytowania

Eleazu O.C., Eleazu K.C., Kolawole S., 2014. Use of indigenous technology for the production of high quality cassava flour with similar food qualities as wheat flour. Acta Sci. Pol., Technol. Aliment. 13(3), 249-256. 